\title{
Cultural Presence of the Cretan Biodiversity in the Minoan Period and nowadays: A Discovery School Teaching Approach
}

\author{
Maria Kalathaki ${ }^{1}$ and Anna Papastefanaki ${ }^{2}$ \\ 1. Regional Educational Directorates of Crete, Heraklion, Crete 71306, Greece \\ 2. Meleses Lyceum, Meleses, 70300, Crete, Greece Heraklion, Crete 70300, Greece
}

Received: February 21, 2014 / Accepted: February 28, 2015 / Published: February 28, 2015.

\begin{abstract}
The educational project prepared for students of High School 15-17 years old with the subject of Biodiversity in Minoan Period and Nowadays. It was an interdisciplinary approach of ecological and cultural views of biodiversity. Special educational material was prepared with photos and texts of archaeological excavations and field sampling which was used in real and virtual environment, in $\alpha$ discovery teaching of Natural Sciences and History subjects. Students, in a scientific research project with constructive teachings, followed the procedures by which scientists gather, analyze, synthesize, process and evaluate information of organisms of Crete since 4000 years. Crete is located between the natural limits of three continents, having the unique privilege to host permanently or in migration, distinctive species of these three continents. After having the research questions, teachers collected the educational material, organized the work groups, implemented the didactic intervention in the classroom, had the field sampling of plants, recognized the synchronous local and scientific names of the plants, constructed the botany book, photographed the collected organisms and all the concentrated material was delivered to the team members.
\end{abstract}

Key words: Biodiversity, discovery teaching method, minoan period, distance education.

\section{Introduction}

In a target based on approaching to educational research, the research itself is a powerful factor in shaping the construction method, the nature of the subject, the learning and their impact on teaching [1]. Although epistemologically science appears to be more suitable as a process based on argument and persuasion rather than discovery [2], the standard of scientific research promoted to students in school science more and more resembles to that Carlsen [2] called "naïve inductivism-epagogismos". The above approach to science teaching in schools results apparently from the teaching methodology usually

Corresponding author: Maria Kalathaki, Ph.D., research field: education and teachers' training in science school cognitives in the framework of the education for the sustainable development. E-mail: kalathakimaria.edu@gmail.com. followed in school courses, where observations precedes the theory and the theory precedes experimentation. The constructivism, having science as initial and main field of research and application, throws light and gives weight to the existing perceptions, representations and ideas of the students with respect to the subject they are studying each time. Thus, learning is the result of changes in the mental models of students as they try to explain their experiences, building step by step knowledge in an energetic way [3].

The scientific research method of a constructive teaching is a set of procedures by which scientists gather, analyze, synthesize, process and evaluate information. The first step is the observation, based on the senses, then follows the wording of the case, the experiment to test the hypothesis, the extraction and 
critical appraisal of the results, the wording of the conclusions, their generalization and predictions for future implementation and utilization [4].

The scientific research method of a constructive teaching is a set of procedures by which scientists gather, analyze, synthesize, process and evaluate information. The first step is the observation, based on our senses, then follows the wording of the case, the experiment to test the hypothesis, the extraction and critical appraisal of the results, the wording of the conclusions, their generalization and predictions for future implementation and utilization [5]. The teaching intervention, described below, took place in 2011 at the Meleses Lyceum in Crete, on Biodiversity during Minoan and current years and attempted to exploit discovery teaching methods for constructive learning of cognitive subjects of natural sciences through these of local history. There was an attempt to teach the concept of biodiversity, as it is described in the school book of the $\mathrm{C}$ grade, which is attributed to the diversity of the phenomenon of life at every level of its organization, that of the genes, the chromosomes, the bodies, the species, the communities and the ecosystems [6].

Crete is located on the natural limits of three continents. This results in the unique privilege to host permanently or in migration, distinctive species of these three continents. Small habitats on the island are particularly critical for the survival of many endemic and non endemic organisms, which are more sensitive to damage and deterioration of the environment [7]. What characterizes the Cretan nature is the variety of life, not the sizes, as cultural heritage and the obligation to preserve it for future generations [8]. For placing the concept in space and time, emphasis was given on the biodiversity of Earth Ecosystems, which was the thematic annual target of the UNESCO Decade for Education of Sustainable Development 2005-2014. This project was designed to meet and satisfy multiple targets of the teaching lessons of Greek Lyceums and the school projects of
Environmental Education.

\section{Methodology}

The research methodology was Case Study with Content-Analysis of the archival material of the educational project and the personal narratives/records /notes of teachers who participated in the project, both of which are coordinated and present writers.

The objectives of inside and outside of classrooms education can be combined and focus on multiple educational, social or physical effects and results [9]. The project focused to the complement of the general education of students, development of collaborative relationships in teamwork, awareness on environmental and cultural issues, detection and cultivation of deeper artistic, technical or scientific inclinations, skills, peculiarities and aesthetic sensibilities of students, awareness of current reality compared with other earlier, in practice and familiarity with scientific research methodologies in teaching, self-education by using libraries, internet and peer learning groups, the development of critical and creative thinking, improve observation and understanding of the value of natural ecosystems and the role of human disorders of balance, exploitation of the knowledge coming from the many and varied school subjects by using the modern means of communication and information dissemination.

This teaching intervention was organized in four learning levels that were conquered by different categories of graded difficulty skills [10]. On the first level, the lower the informational, learning involves collecting information through the senses and memory functions which the person usually expresses with the speech. On the second level, the organizational, learning through comparison, classification, structure and hierarchy makes interrelationships of the data which eventually integrate into a broader conceptual schema. At the third level, the analytical, learning refers to intra-data correlations sought through analysis processes and inductive reasoning processes. 
Finally, on the fourth level, the practical, the person uses, in a deductive way, the organized into patterns, principles, and models knowledge to explain, interpret, predict, evaluate, reorganize and overcome beyond the surface data structures.

The project work was carried out in the classroom, in the field, in the school library and laboratory of Natural Sciences and at homes. In the classroom, 21 students were divided into 7 groups of 3 people with a laptop in each group. The digitized educational materials distributed to laptops with portable hard drive and students, following the instructions of the worksheet, navigated the images to attribute the modern name to organizations (plants and animals) of the Minoan frescoes simulating modern. This material was used in all the phases of the project. After having been the research questions, teachers collected the educational material, organized the work groups, implemented the didactic intervention in the classroom, had the field sampling of plants, recognized the synchronous local and scientific names of the plants, constructed the botany book, photographed the collected organisms and all the concentrated material was delivered to the team members.

\section{Design and Implementation of the Project}

\subsection{Setting the Educational Queries}

Some questions entered in the working groups and some others encountered and discussed on the implementation progress, because they emerged as a need:

(1) Names of plants and animals of Minoan times and names of the similar currents;

(2) Correlation of the existence of the illustrated organisms with the geophysical and environmental conditions that probably prevailed at that period in Crete and the sociopolitical data of that season in the eastern Mediterranean;

(3) Plants were grown and animals reared during the Bronze Age in Crete;
(4) Nerve color perception and sensation in the eyes;

(5) Materials that characterize each historical period, with emphasis in Minoan one;

(6) Emotions that generate images-physiocratic period in Art;

(7) The eruption of Santorini volcano, the ash that covered Crete and the destroy of the Minoan Civilization;

(8) Environmental ethics, ecological and cultural values lost with the disappearing species and natural resources that are depleted, e.g. over-exploitation of copper and iron ore since antiquity;

(9) Languages of symbolism and Science in ancient times in Crete (Hieroglyphics, Linear A \& B);

(10) Identification of animals and plants of the Bronze Age in Crete that are not recognized in the current years. The biodiversity loss as threat of ecosystems stability;

(11) Plants that were used by Minoans' everyday life as for cosmetics, incense, etc.;

(12) Maintenance materials, additives and spices of foods then and now;

(13) Chemicals of paint and drawing;

(14) Copper metallurgy, trade, imports and exports;

(15) Manufactures of Minoan time, such as textiles, winery, pottery, stone cuttering, sealing, micro sculpture, fagentianourgy, metalwork, etc.;

(16) Co-evolution of plants and insects with joint benefit in pollination and diet-species partnerships;

(17) Findings of seeds, nuts, olives and grapes in Crete in the Bronze Age;

(18) Mediterranean diet, much discussed, and of great value, based on the diversity of native plants and herbs, which, however, in recent years in Crete has changed towards western models.

\subsection{Collecting the Educational Material}

The educational material was selected and organized in such a way as to answer the queries of the didactic research. Learning is better when the 
material is organized around general principles and explanations instead of relying on memorizing isolated facts and procedures [32]. The specially selected educational material/multimodal teaching text given to the students face to face or remotely, inside and outside the school, helped them to understand the function of scientific research into investigation of ecological and archaeological issues, some of which are related to the their daily life (diet, social habits).

At the beginning of the project, extensive literature was proposed to the students, mostly in printed form, from guides of archaeological museums, empirical keys for identification of plants, articles from journals and lemmas from encyclopedias, such as "Insert Issue National Geographic February 1999 Greek version" [11], "Prehistory and Protohistory, History of the Greek Nation Volume D" [12], "Wild Flowers of Crete" [13], "Plants of Crete Medical, Aromatic and Edible" [14], "The Endemic Plants of Cyprus" [15], "The Medicinal Plants of Cyprus" [16], "Animals and Plants of Southern Greece which are under pressure because of their economic importance, Archi-Med Protection of Endangered Endemic Species Program in Southern and Eastern Mediterranean" [17], "The cultural value of plants and animals in Crete from the Neolithic Age to today, Archi-Med Program" [18], "Durable Mediterranean Plants" [19], "Trees and Shrubs of Greece" [20], "Crete: All Museums and Archaeological Sites" [21], "Heraklion Museum Illustrated Guide" [22], "Phaistos-Gortyn-St. Triada-Prinias-Kommos-Miamou-Lendas-Matala-St.

Galini-Inatos" [23], "In Minoan Crete" [24], "Crete Archanes" [25], "History of Cyprus from the Neolithic to the Roman era, school book" [26].

In the studied material containing images of plants and animals of Minoan era of archaeological finds in Crete and Cyprus, such as vases, decorative objects, jewelry, gems and paintings. The digitized images of the Minoan times and reading texts of the mentioned books, and others, enabled zoom, rotation and more detailed glance on the illustrated organisms, as if they were the object-finding itself. Students elaborated, in a virtual environment, research materials similar to those Biologists and Archaeologists study.

\subsection{Development of the Phases of the Project}

The didactic intervention of the project took place in the classroom. The students navigated the photos of the archeological findings and recorded the names of the current animals and plants those are similar. They also made some notices of the most impressive legends. Students recorded what mainly are illustrated on frescoes, like spirals, rosettes, whole plants or their parts as flowers, rocks, animals etc.. Animal identification proved easier than plants. The identified organisms are contained in Tables 1 and 2. Of special interest was "partridges and dolphins of the diazoma of the Knossos hostel that perhaps represented royal gardens with exotic birds", also "the ornamental faience in the treasury of Knossos represented chamois and heifers breastfed their babies" as students noted in their work sheets.

The materials of the findings of the studied period which recorded were sardonyx, stearic, carnelian, hematite, clay, chlorite, faience, slate, gold, copper, ivory and more. As for jewelry, students noted "golden mosaic of a small lion in a necklace of burial outline of Agia Triada Archanon", "necklace with two wasps that suck a drop of honey from Chrysolako Malia", "golden mosaic duck necklace of the Palace of Knossos". As for the sealstones, they were mentioned "chrysodetos sealstone with lion and its tame", "a sealstone of hematite with lioness attacking a bull devouring it, found at Knossos Palace".

The observation of Minoan frescoes through their painting representation in the book "In Minoan Crete" of teacher Tachataki [24] enabled focus only on that parts of the frescoes which experienced painter chose to re-draw by isolating the part out of the whole. In this way, many issues of the original frescoes, which had escaped the first observation, received finally special attention. Tachataki [24] functioned as 
Table 1 Animals of Minoan Findings.

\begin{tabular}{|c|c|c|}
\hline$\alpha / \alpha$ & Modern name & $\begin{array}{l}\text { Number of student } \\
\text { groups that have } \\
\text { recognized it }\end{array}$ \\
\hline 1 & cow & 3 \\
\hline 2 & wildcat & 6 \\
\hline 3 & boar & 6 \\
\hline 4 & eagle & 1 \\
\hline 5 & Ibex (krikri) & 6 \\
\hline 6 & horse & 6 \\
\hline 7 & bear & 1 \\
\hline 8 & lamb & 5 \\
\hline 9 & sea urchin & 6 \\
\hline 10 & frog & 2 \\
\hline 11 & donkey & 1 \\
\hline 12 & Gorgon & 1 \\
\hline 13 & griffin & 6 \\
\hline 14 & dolphin & 7 \\
\hline 15 & deer & 4 \\
\hline 16 & elephant & 4 \\
\hline 17 & camel & 1 \\
\hline 18 & goat/Goat & 6 \\
\hline 19 & shell & 3 \\
\hline 20 & lion / lioness & 6 \\
\hline 21 & bee & 6 \\
\hline 22 & fly & 6 \\
\hline 23 & nautilus & 2 \\
\hline 24 & panther & 6 \\
\hline 25 & duck & 2 \\
\hline 26 & peacock & 6 \\
\hline 27 & partridge & 7 \\
\hline 28 & butterfly & 5 \\
\hline 29 & dove & 6 \\
\hline 30 & ape & 6 \\
\hline 31 & bird & 3 \\
\hline 32 & lizard & 1 \\
\hline 33 & scarab & 4 \\
\hline 34 & Scorpio & 1 \\
\hline 35 & $\operatorname{dog}$ & 6 \\
\hline 36 & taurus & 7 \\
\hline 37 & snake & 4 \\
\hline 38 & winged horse & 4 \\
\hline 39 & chamelaiontas & 6 \\
\hline 40 & octopus & 6 \\
\hline 41 & fish & 5 \\
\hline
\end{tabular}

naturalists in the past who reflected on the paper with a pencil what that they were able to see on the studied organisms. The same task was asked students to do at home for an archaeological finding of their choice and
Table 2 Plants of Minoan Findings.

\begin{tabular}{lll}
\hline a/a & Modern name & $\begin{array}{l}\text { Number of student } \\
\text { groups that have } \\
\text { recognized it }\end{array}$ \\
\hline 1 & vineyard/Grape & 2 \\
2 & acorn & 1 \\
3 & daphne & 1 \\
4 & reed & 5 \\
5 & ivy & 6 \\
6 & barley & 3 \\
7 & lily & 6 \\
8 & yolk & 5 \\
9 & margaret & 5 \\
10 & pea & 1 \\
11 & papyrus & 1 \\
12 & pine & 2 \\
13 & garlic & 1 \\
14 & grain & 6 \\
15 & tulip & 3 \\
16 & palm & 6 \\
17 & seaweed & 4 \\
\hline
\end{tabular}

then to consider which parts of the original had initially noticed and which at the end of their drawing. Students, based on logic and in step-by-step data processing, tried to take into account those details that could help them reach the "big picture". The understanding of the whole, with inductive-deductive reasoning, was taking advantage of the imagination and creativity, ultimately satisfying their curiosity [27].

\subsection{Homework}

Some students from Crete continued at home searching similarities between the illustrated organisms on the Minoan findings and the modern ones, comparing the photos in the digital files of educational material and other references from school books, such as Refs. $([26,28,6])$ and given bibliography. Some of the retrieved references from the school books were the following: "The technique of treating the copper was the latest technology of the Era", "The Minoans also import metals from Gytheio". According to ancient written sources the ancient Githeio served as commercial (Strabo, Geography 8.5.2) and military port (Xenophon, Greek VI 5.30). It is located 5 meters 
below the seabed, and is approximately $220 \mathrm{~m}$ long and $70 \mathrm{~m}$ wide. The first signs of commercial activities in the surrounding area date from the Bronze Age, when the Krokeatis stone (Lapis Lacaedemonius), from local stone-pits in Krokees and Psefi, is exported in Crete and Mycenae. Later the natural harbor of Gythio probably becomes the center of the Phoenician trade in purple [12].

\subsection{Field Sampling of Plants}

To view past into present and test the new knowledge into new environments of everyday life, some of the species of plants and animals that were discussed in class within the course, were sought in the fields of the school area in Crete as a field activity during a school walk in November 2010 in the countryside. The collection of plants for identification and construction of herbarium was made from random points of the field by uprooting the whole plant when its dimension was smaller than an A4 sheet, otherwise by cutting off standard parts of the root, the trunk, the leaves, the flower, characteristics that would help to give an empirical name. The determination of the scientific name of the genus and species of some plants was done by using a key definition and by using the empirical name found in Google, and also with the assistance of the Agronomist school teacher in the field and in the Natural Sciences lab.

The students were also helped in naming by the observation of some plant parts such as flower legume that, for example, looks like as soul (butterfly psychanthi), the distinguished smell, such as the dill from the fennel or from the information that the rabbits eat it (rabbit plant-lagoudochorto). Some of the species edible by animals and humans, which were discussed during sampling and construction of herbarium, were the mallow, fennel, mantilida, achatzikos, lagoudochorto, agalatsida, curmudgeon, pikromaroula, gournovizi, glykosirida, thyme. The names are empirical, that used in the local dialect.

During sampling, a square frame area of $1 \mathrm{~m}^{2}$ was placed in five different places rich in green where different edible, by humans and animals, plant species were identified and counted, without being uprooted. On average nine (9) different plant species were recorded in each block of sampling, five (5) edible by humans and two (2) non-edible by animals. The presence of these species has to do with the seasons in the Mediterranean ecosystems, so it is good to repeat in March and in June the same sample, to record also the changes in the composition of plant communities in the same field with the seasons. The plants involved in the landscape, create aesthetic values with foliage, colors, structures, smells and fresh air. The flora that gives aesthetic pleasure, has been adapted to the environmental conditions and served as a memory point and reference inextricably linked with the landscape [19]. Apart from the types of plant community of the field that were identified, a lot of other animals (especially insects) were also identified.

\subsection{Creating a Botany Book}

The main objective of the construction of the herbarium was to distinguish some less frequent than other plants that exist in an area, and learn some empirical names. During the digital photographing of plants in the field and in the Natural Sciences lab, where the herbarium was constructed, there was discussion and comparison with similar organizations from the Minoan findings in Heraklion. Overall 32 different plants were collected to enter the herbarium and were recognized by their local, empirical name. In some of them, after being assigned by their scientific name, the plant samples were placed in a cardboard herbarium and were photographed. The selected representative plant parts, were placed between cardboard sheets of the Botany Book with written the empirical name of the plant it belongs [29]. The plants placed in the herbarium were: Agarathos, agoutsakas, agriomaintanos, apourantza, rosemary, askrolympos, daffodil, achatzikos, vetch, spurge, glykosirida, thyme, Kolitsani, saffron, lagoudochorto, lapsanida, 
lychnarakia, crown daisy, fennel, mallow, potato, pikromaroula, leek, chicory/gournovizi, skylokremyda, curmudgeon, alfalfa, finokalia, mullein, choiromourida.

The herbarium was stored in the school library and the digital form was sent to the students by e-mail to use it in the comparison while researching for animals and plants in the period of the last 3500 years.

\section{Conclusions}

The central aim of the project was to sustain students to give rise their Life Long Learning, to learn how to deepen in scientific issues which are related to the everyday life and promote its quality. Thus, the applied didactic research was both a pedagogical strategy and a learning objective. The genetic wealth of plants is the result of the natural selection and evolution, adaptation to the local climate, management and perception of the value and beauty that has. Students could see how people are directly dependent on the life cycle of plants, and why people stood in awe of the earth and worshiped, for thousands of years. The cult of the earth, gave birth deities of vegetation by symbols plants with flowers in hands, with wreaths on the head with tufts cereal in their arms, which decorated altars and burned incense, as Rizopoulou refers [19].

Biology and History taught as investigation. Students had the chance to realize in fact that the knowledge is generated by the interpretation of the data, that this interpretation of the data proceeds into the base of concepts and assumptions and change with increasing knowledge and thus, these principles and concepts are changing, knowledge is changing also [30]. In the integrated approaches, the boundaries between discrete disciplines of study are crossed or even eliminated. They emphasized in an issue or topic and investigated it through thematic ideas, by integrating disciplines of study and allowing learners to make connections to real-life issues that are relevant to them. [31]. Outdoor education and environmental education are inter-related as two methods of a process that aim to facilitate change in the individual through learning [9].

As research shows that people need to do a lot of practice to gain experience in a field and even small differences in the time we are exposed to the information which may have big differences to the information they obtain [32], it is of high priority in schools to design their educational projects with the target of practice students in finding, choosing and exploiting information for improving the quality of thought and life. Nature with the biodiversity, the images, the sounds, the smells, its mechanisms and energy teaches people key relationships that define the life, indirectly fixes the principle of the measure and the limits, inspires patience with its own rhythms that characterized by maturation, maturity, wisdom [33].

\section{References}

[1] Robottomt, I. 2004. "Constructivism in Environmental Education: Beyond Conceptual Change Theory." Australian Journal of Environmental Education 20 (2).

[2] Carlsen, W. S. 2001. "The Sociological Context of Environmental Science and its Use in Rethinking Scientific Inquiry." Presented at the annual meeting of the National Association for Research in Science Teaching, St. Louis, MO, March 25-28, accessed February 20, 2015, http://ei.cornell.edu/pubs/.

[3] Osborne, R., and Freyberg, P. 1985. Learning in Science. The Implications of Childrens 'Science. Heinemann

[4] Olssen, M. 1996. "Radical Constructivism and its failings: Anti-Realism and Individualism." British Journal of Educational Studies 44 (3).

[5] Athanasakis, A., Koysoyris, I., and Kontaratos, P. 2008. Environmental Science Principles, Second Grade High School. Edited by the Organization of Textbooks, Athens

[6] Kalaitzidaki, M., and Pantazidis, C. 2003. Biology General Education C Lyceum, Edited by OEDB, second edition, Athens

[7] Georgiou, K., and Delipetrou, P. 2001. Threatened Endemic flora in southern Greece, Archi-Med Protection of Endangered Endemic Species Program in Southern and Eastern Mediterranean Region of Crete-Regional Fund, Edited by the Natural History Museum of Crete, Heraklion

[8] Gkiokas, S. 2001. Threatened Endemic Species of 
Terrestrial Fauna in southern Greece, Archi-Med Protection of Endangered Endemic Species Program in Southern and Eastern Mediterranean Region of Crete-Regional Fund, Edited by the Natural History Museum of Crete, Heraklion

[9] Parkin, D. 1998. "Is Outdoor Education Environmental Education?" International Journal of Environmental Education and Information 17 (3): 275-86.

[10] Matsagouras, H. 2007. Teaching Strategies, 5th edition, Athens: Edited by Gutenberg.

[11] National Geographic Society. 1999. Biodiversity Millennium Maps, Inset issue National Geographic February 1999, Edited by NGS, Greek version.

[12] Alexiou, S. 1970. Prehistory and Protohistory, History of the Greek Nation Vol A, Published in Athens

[13] Sfikas, G. 1994. Wild Flowers of Crete, Greek Nature, Edited by Efstathiadis group, Athens

[14] Alibertis, A. 1989. Plants of Crete Medical, Aromatic and Edible, Edited by Mystis, Heraklion

[15] Tsintidis, T. 1995. The Endemic Plants of Cyprus, Edited by the Bank of Cyprus Pancyprian Association of Professional Foresters, Nicosia, Cyprus

[16] Zannettou-Pantelis Sunday. 1998. Medicinal Plants of Cyprus, Edited by Print Co Ltd, Larnaca, Cyprus

[17] Papageorgiou, N. 2001. "Animals and Plants of Southern Greece under Pressure Because of Their Economic Importance." Archi-Med Protection of Endangered Endemic Species Program in Southern and Eastern Mediterranean Region of Crete-Regional Fund. Edited by Natural History Museum of Crete, Heraklion

[18] Kyriakides, E. 2001. "The Cultural Value of Plants and Animals in Crete from the Neolithic Age to Today." Archi-Med Protection of Endangered Endemic Species Program in Southern and Eastern Mediterranean Region of Crete-Regional Fund, Edited by Natural History Museum, Heraklion

[19] Rizopoulou, S. 2008. Durable Mediterranean plants. Course Notes of Special Teaching in MSc Program"Current trends in the teaching of biological courses and new technologies" of the Department of Biology, University of Athens

[20] Sfikas, G. 1998. Trees and Shrubs of Greece, Greek Nature,Edited by Efstathiadis group, Athens

[21] Kofos, A. 1990. Crete: All Museums and Archaeological Sites, Publishing Athens, Athens
[22] Sakellarakis, J. 1997. Museum of Heraklion Illustrated Guide, Publishing Athens

[23] Vlachos, I. 2007. Notes General Teaching at MSc Program "Current trends in the teaching of biological courses and new technologies", Department of Biology, University of Athens

[24] Tachataki, I. 2000. In Minoan Crete, Greek Mythology series, Edited by Smyrniotakis, Heraklion

[25] Sakellarakis, J. E. 1991. Crete-Archanes, Edited by Ekdotiki Athinon, Athens

[26] Pantelidou, A., Chatzikosti, K., Christos, I., and Protopapas, K. 1990. History of Cyprus from the Neolithic to the Roman era, School textbook, Edited by Ministry of Education and Culture of Cyprus

[27] Vlachos, I. 2007. Notes General Teaching at MSc Program "Current trends in the teaching of biological courses and new technologies", Department of Biology, University of Athens

[28] Mastrapas, A. 2007. History of the Ancient World, A Lykeiou- School book, Edited by OEDB, Athens

[29] Kokkini, S., Karoussos, P., and Drouzas, A. 2014. Creation of herbarium-Suggestions for plants that we can find, Lesson Systematic Botany, Faculty of Agriculture, University of Athens, accessed on November 4, 2001, http://www.agro.auth.gr/ old_website/ anakoinoseis/ 2014 / 2014-04-11-01.pdf

[30] Athanasiou, K. 2008. Discovery teaching method. Course Notes of Special Teaching in MSc "Current trends in the teaching of biological courses and new technologies" of the Department of Biology, University of Athens, Edited by Athanasiou, Athens

[31] Meredith, J. 2000. Best practices for Environmental Education: guidelines for success Ohio EE 2000: a strategic plan for environmental education in Ohio, Environmental Education Council of Ohio, accessed Febryary 20, 2015. http://www.epa.state.oh.us/other/oeef/oeemain.html.

[32] Vosniadou, S. 2001. How students learn, the UNESCO International Bureau of Education / International Academy of Education, accessed March 12, 2014. http://www.ibe.unesco.org/publications/EducationalPracti cesSeriesPdf/prac07gr.pdf

[33] Bazigos, P. 2006. June 5: World Environment Day. Man in the World Environments, accessed March 7, 2007. www.inArcadia.gr. 